\section{Living on Borrowed Time}

\author{
Marcie Gibson
}

I don't remember the date I was diagnosed with ALS. It was a regular, clear, sunny Texas day in January of 1994. I have intentionally forgotten that date; I don't want a dreaded yearly anniversary. That day I walked into Dr. Barohn's office with a full life ahead of me and walked out with virtually no future at all. I didn't ask why me, I asked why not me. The human body is so complex, I don't know how any of us are walking around seemingly healthy. I was 23 , in my last semester of college, had just gotten engaged, was about to pursue some plans I had set in place since elementary school, and was looking forward to starting a life with my soon-to-be husband. All that seemed so frivolous when faced with mortality. I had waited too long to start my socalled adult life; now it was too late. Death was the farthest thing from my mind. I wrongly thought I had time. Naively, I thought I would have chance after chance of opportunities. That was a hard lesson learned. I wouldn't have hesitated as much as I did if I could have a do-over. My life had changed with just a few words. So, what do I do now?

I lived in a fog for the first six months, and I don't remember much. I numbly went through the routine of going to school and going to work. I decided to adopt the recovering addicts' philosophy of living pretty early on: one day at a time. When I woke up in the morning, I would focus only on getting through that day. If I started to think about six months or a year into the future, I would be overwhelmed with the difficulties that were to come. I still live this way today. I have a hard time thinking about even two days from now.

In February of 1996 my first nephew was born. I remember saying to myself that I would never see this baby graduate from high school. Not only have I seen him graduate from high school and college, I also saw him get married and grow into a funny, intelligent, confident young man. I have experienced friends getting married, having kids, more nephews and a niece, concerts, SEC college band practice, and other "normal" life occurrences. Sitting in Dr. Barohn's office that terrible day, I didn't see normal life occurrences in my future. I have been given more time than I ever imagined. There are two approaches to life, one as a participant and the other as a spectator. I have lived both. In my pre-ALS life I was very involved in gymnastics, cheerleading, and dance. Now, I am on the sidelines. I prefer being in the middle of things which makes this life, my second life, much tougher.

I had a feeding tube inserted in the summer of 2004. There's something liberating about not eating by mouth. I don't have to think about what I want to eat, I don't have to make it, eat it, or clean up the mess. It frees up a lot of time and energy. Additionally, I get nutrient-dense food without concern for taste. I rarely crave food. I think the connection between my stomach and my brain has been severed. Is that even possible? I take it as a blessing. I can't, however, say it's liberating to lose the ability to breathe. On my 36th birthday my lungs finally gave out. I took the hard path, I chose life. It can be stressful depending on a machine to breathe. There's a tiny part of my brain that's continuously monitoring the vent. First, I ask myself: "am I breathing, vents do fail without warning, was my inhale the right depth, was that a complete exhale, was the timing between breaths as it should be." That part of my brain is constantly on overload. It can get exhausting.

It has been 27 years since I first thought I only had a few years left to live. How have I navigated through this unceasing reminder of death without going insane? One word. . Faith. I am a Christian. I believe life has meaning; life has purpose. Because of my Biblical worldview I don't believe we are grown-up sea sponges; I don't believe we are no different than ants. My life has value, no matter how small of a life I live. If I didn't believe this I would have ended my life the day I was diagnosed. Why face a life of roundthe-clock struggle if life has no purpose and meaning? Hope goes along with Faith. I have to believe that something better may be around the corner. I have to believe that I may see a treatment for ALS and get a second chance with a strong body. If I didn't have hope I would fall into a destructive cycle of depression and despair. None of us can live without hope. My life isn't easy; I have dark days, but I have a lot of joyful days too. Kind of sounds like all of us. I do wonder why I didn't get to be a wife and a mom like $100 \%$ of my circle of friends. Why out of all the diseases, did I contract ALS? These are questions I probably won't get answered until I'm standing in the presence of the Creator. And then, will I even care?

Today, I still live in Texas in the house I grew up in. Fortunately, my parents are healthy enough to care for me. This November 2021 I will be 5l; I never thought I would see 25 . To the world, I am living in that place beyond borrowed time. As a Christian, I know my life will end on the exact day and exact minute that was planned before I was born. What I'm going through isn't a surprise to God. For some reason it took a terminal disease to get me to open my eyes to reality. I was a little blinded. I see my sister and brother's families at least weekly. I have a few friends who have stuck by me throughout this whole illness that I also see. My family and friends are the brave ones. They have chosen to look suffering in the face year after year. Most people rightfully cringe and retreat at the sight of suffering. 
What's On Your Mind?

Not those committed to me, especially my mom and dad who haven't once threatened to put me in a nursing home, even on the worst of days when all they really want to do is throw me out the window. The fiancee? You already know the answer; he ran. Wouldn't you? If I had been given the choice, I would have run for my life away from ALS too. But there's something positive about a terminal disease, it burns away the useless insecurities that get in the way of seeing what's true. Like family, friends, peace, contentment, humility, gratitude, and maybe a little happiness. I have a strange wish: that everyone be misdiagnosed with a terminal disease. The mistake must be concealed for a least one year. A month or two isn't long enough to realize the blessings mentioned above resulting in positive impacts to yourself and those around you without actually losing your life. Hopefully, anyone reading this article has realized this idea for yourself from interactions with your chronic/terminally ill patients. Live life knowing that good health is a gift not everyone receives. 